\title{
The effect of flap thickness on corneal biomechanics after myopic laser in situ keratomileusis using the M-2 microkeratome
}

This article was published in the following Dove Press journal:
Clinical Ophthalmology

Number of times this article has been viewed

\author{
lyad A Goussous' \\ Mohamed-Sameh El-Agha' \\ Ahmed Awadein' \\ Mohamed H Hosny' \\ Alaa A Ghaith ${ }^{2}$ \\ Ahmed L Khattab ${ }^{2}$ \\ 'Department of Ophthalmology, \\ Faculty of Medicine, Cairo University, \\ Cairo, ${ }^{2}$ Faculty of Medicine, Alexandria \\ University, Alexandria, Egypt
}

Purpose: The purpose of this study was to determine the effect of flap thickness on corneal biomechanics after myopic laser in situ keratomileusis (LASIK).

Methods: This is a prospective controlled non-randomized, institutional study. Patients underwent either epi-LASIK with mitomycin (advanced surface ablation [ASA]), thin-flap LASIK (90 $\mu \mathrm{m}$ head), or thick-flap LASIK (130 $\mu \mathrm{m}$ head). In ASA, the Moria Epi-K hydroseparator was used. LASIK flaps were created using the Moria M-2 mechanical microkeratome. The corneal hysteresis $(\mathrm{CH})$ and corneal resistance factor $(\mathrm{CRF})$ were measured preoperatively and 3 months after surgery, using the Ocular Response Analyzer ${ }^{\circledR}$.

Results: Ten patients (19 eyes) underwent ASA, 11 patients (16 eyes) underwent thin-flap LASIK, and 11 patients (16 eyes) underwent thick-flap LASIK. The mean preoperative $\mathrm{CH}$ was $10.47 \pm 0.88,10.52 \pm 1.4$, and $11.28 \pm 1.4 \mathrm{mmHg}(p=0.043)$, respectively, decreasing after surgery by $1.75 \pm 1.02,1.66 \pm 1.00$, and $2.62 \pm 1.03 \mathrm{mmHg}(p=0.017)$. The mean reduction of $\mathrm{CH}$ per micron of central corneal ablation was $0.031,0.023$, and $0.049 \mathrm{mmHg} / \mu \mathrm{m}(p=0.005)$. Mean preoperative CRF was $10.11 \pm 1.28,10.34 \pm 1.87$, and $10.62 \pm 1.76 \mathrm{mmHg}(p=0.66)$, decreasing after surgery by $2.33 \pm 1.35,2.77 \pm 1.03$, and $2.92 \pm 1.10 \mathrm{mmHg}(p=0.308)$. The mean reduction of CRF per micron of central corneal ablation was $0.039,0.040$, and $0.051 \mathrm{mmHg} / \mu \mathrm{m}(p=0.112)$.

Conclusion: Thick-flap LASIK caused a greater reduction of $\mathrm{CH}$ and $\mathrm{CRF}$ than thin-flap LASIK and ASA, although this was statistically significant only for $\mathrm{CH}$. ASA and thin-flap LASIK were found to be biomechanically similar.

Keywords: flap thickness ectasia, hysteresis, LASIK, surface ablation

\section{Introduction}

One of the most dreaded complications of laser in situ keratomileusis (LASIK) is corneal ectasia. ${ }^{1}$ Although risk factors for post-LASIK ectasia have been identified, ectasia has also been found to occur in apparently "normal" eyes, where corneal topography and thickness data implied a low risk of developing postoperative ectasia. ${ }^{2,3}$ Hence arose the need for a noninvasive method of directly measuring the biomechanical strength of the cornea, rather than inferring this strength indirectly from tomographic data. The Ocular Response Analyzer ${ }^{\circledR}\left(\mathrm{ORA}^{\circledR}\right.$; Reichert Instruments, Depew, NY, USA) was developed to achieve this goal. ${ }^{4}$ It measures corneal hysteresis $(\mathrm{CH})$, a viscoelastic property of the cornea, and the corneal resistance factor (CRF), the elastic resistance of the cornea. ${ }^{5}$

Despite the apparent superiority of surface ablation over LASIK in terms of corneal biomechanics, LASIK continues to be very popular among surgeons and patients, due to less pain, quicker visual rehabilitation, much lower incidence of haze, and less need
Correspondence: lyad A Goussous Department of Ophthalmology,

Faculty of Medicine, Cairo University, Cairo II562, Egypt

Tel +20 I062453343

Email dr.iyad.goussous@hotmail.com 
for postoperative medications. ${ }^{6}$ It is therefore important to determine the effect of LASIK flap architecture on corneal biomechanics.

A number of studies have measured $\mathrm{CH}$ and $\mathrm{CRF}$ after creating LASIK thick flaps and comparing them to epiLASIK or photorefractive keratectomy (PRK). ${ }^{7,8}$ They used microkeratomes to create thick flaps, up to 160 and $180 \mu \mathrm{m} .{ }^{9}$ These studies did not compare the effects of different flap thicknesses on corneal biomechanics. We assume that a thinner flap would retain the benefits of LASIK and have lesser effect on the corneal biomechanics, similar to the effect of advanced surface ablation (ASA).

In this study, we aimed to compare the corneal biomechanical changes after thin-flap LASIK ( $90 \mu \mathrm{m}$ head) and thick-flap LASIK (130 $\mu \mathrm{m}$ head) with those after ASA (epiLASIK with mitomycin).

\section{Methods}

The study was carried out in two centers, the Ophthalmology Departments of Cairo University and Alexandria University (Egypt). The study was approved by the research ethics committee of Cairo University and Alexandria University. The study and data collection conformed to all local laws and were compliant with the principles of the Declaration of Helsinki. Written informed consent for the surgery and study was obtained from all patients. A prospective non-randomized comparative cohort study was carried out on eligible patients presenting to both centers, and requesting keratorefractive surgery during the period from February 2010 to January 2012. Inclusion criteria included patients with myopia or compound myopic astigmatism with spherical error ranging from -2.00 to $-6.00 \mathrm{D}$, and cylindrical error ranging from 0 to $-4.00 \mathrm{D}$. Patients were counseled regarding both ASA and LASIK, and were given the choice between the two procedures. When patients chose LASIK, it was left to the surgeon to choose between a $90 \mu \mathrm{m}$ (L-90 group) and $130 \mu \mathrm{m}$ (L-130) microkeratome head. All surgeries were done by MSE, MH, and AG. The preoperative evaluation, surgical steps, and postoperative treatment were similar in both centers.

Patients underwent manifest and cycloplegic refraction, to ensure that the difference between the two did not exceed $0.5 \mathrm{D}$. The refractive target in all eyes was emmetropia. All patients had $\mathrm{CH}$ and $\mathrm{CRF}$ measurements within 2 weeks before surgery. Measurements were taken using the ORA.

Patients underwent a preoperative screening examination to determine contraindications to ASA and LASIK in general, and factors that may confound the biomechanical evaluation of the cornea in particular. Systemic exclusion criteria included age $<21$ years, presence of diabetes mellitus, pregnancy, lactation, or collagen vascular disease. Refractive contraindications included unstable refractive error, and poor spectacle-corrected visual acuity secondary to irregular astigmatism. Ocular exclusion criteria were dry eye syndrome, corneal hypoesthesia, ectatic corneal conditions, endothelial corneal dystrophies, previous ocular surgery, glaucoma, visually significant cataract, and retinal or optic nerve disease limiting vision.

All patients underwent preoperative evaluation, within 2 weeks before the surgery, of corneal thickness and corneal topography using the same Scheimpflug-based corneal tomography system (Oculyzer ${ }^{\circledR}$; Oculus Optikgerate, Wetzlar, Germany).

For ASA, epithelial separation was achieved mechanically by hydroseparation using the Epi-K $\mathrm{K}^{\circledR}$ microkeratome (Moria, Antony, France). After stromal ablation, mitomycin $0.02 \%$ was applied using a microsponge for a duration of 20 seconds. The stromal bed was then irrigated thoroughly with $10 \mathrm{~mL}$ of chilled balanced salt solution. Topical antibiotic (gatifloxacin $0.3 \%$ ) was applied followed by a bandage contact lens. The patient continued to apply antibiotic drops until full epithelialization occurred, usually 4-5 days after surgery, at which point the bandage contact lens was removed. Topical steroid (fluorometholone 1\%; Allergan, Irvine, CA, USA) was used for 6-8 weeks with a gradual taper, together with preservative-free lubricants for 2-3 months.

In LASIK patients, the superior hinged flap was created by a single-use $\mathrm{M}-2^{\circledR}$ microkeratome (Moria), using either the 90 or $130 \mu \mathrm{m}$ head. The same head and blade were used for both eyes in bilateral cases. Topical steroids (prednisolone acetate 1\%; Allergan, Irvine, CA, USA) and antibiotics (gatifloxacin 0.3\%; Jamjoom Pharma, Jeddah, Saudi Arabia) were used for 1 week after surgery. Preservative-free lubricants were then used for 2-3 months.

Laser ablation in all cases (ASA and LASIK) was performed by the Allegretto WaveLight ${ }^{\circledR}$ Eye-Q excimer laser (Alcon, Fort Worth, TX, USA), using wavefront-optimized ablation, with an optical zone ranging from 6.0 to $6.5 \mathrm{~mm}$.

Uncorrected visual acuity, corrected distance visual acuity, and spherical equivalent were evaluated before and 3 months after surgery. Postoperative measurements of $\mathrm{CH}$ and CRF were taken at least 3 months (3-4 months) after surgery, to ensure stabilization of $\mathrm{CH}$ and $\mathrm{CRF} .{ }^{10}$

Statistical analysis was carried out using group means, comparing the ASA group to each of the two LASIK groups, and also comparing the two LASIK groups to each other. 
Analysis of variance (ANOVA) was used to compare the three groups together. In addition, a double-tailed, unpaired Student's $t$-test was used for comparisons between all possible combinations of groups. Statistical analysis was performed using SPSS for Windows (SPSS Inc, Chicago, IL, USA).

\section{Results}

A total of 33 patients (51 eyes) were included in the study. Ten patients (19 eyes) underwent ASA, 11 patients (16 eyes) underwent LASIK with a $90 \mu \mathrm{m}$ head, and 11 patients (16 eyes) underwent LASIK with a $130 \mu \mathrm{m}$ head. Table 1 summarizes the pre and postoperative data in the three groups.

In general, there was no significant difference between ASA and L-90 and ASA and L-130 groups in terms of age, preoperative manifest refractive spherical equivalent, preoperative central corneal thickness (CCT), central ablation depth, and the preoperative $\mathrm{CH}$ and CRF (Table 1; Figure 1). However, ANOVA testing comparing the three groups together showed a $p$-value of 0.012 for preoperative cylinder, since the L-90 group had a higher mean preoperative cylinder than the other two groups. Similarly, the $p$-value for ANOVA for preoperative $\mathrm{CH}$ was 0.043 , probably due to the higher preoperative $\mathrm{CH}$ in the $\mathrm{L}-130$ group. This higher $\mathrm{CH}$ value in the L-130 group may be due to the fact that surgeons tended to use thick flaps in thicker corneas that were expected to have higher $\mathrm{CH}$ values.

Following laser ablation, there was a significant reduction in $\mathrm{CH}$ in all groups (Figure 2). Although the mean central ablation depth was similar in all three groups ( $p=0.163$ ), the thick-flap LASIK group had the greatest mean reduction in $\mathrm{CH}(2.62 \mathrm{mmHg})$. The reduction was significant compared to both the thin-flap LASIK $(1.66 \mathrm{mmHg}, p=0.012)$ and the ASA group $(1.75 \mathrm{mmHg}, p=0.017)$. The reduction in $\mathrm{CH}$ in the ASA group was quite close to that in the thin-flap LASIK group ( $p=0.805$ ).

Similarly, there was a significant reduction in CRF in all groups (Figure 3). The mean reduction was greater in the thick-flap LASIK group ( $2.93 \mathrm{mmHg}$ ) than both the thin-flap LASIK $(2.77 \mathrm{mmHg}$ ) and the ASA group ( $2.33 \mathrm{mmHg})$. The difference in the reduction in CRF was statistically insignificant ( $p=0.308$ ). The reduction in CRF in the ASA group was closer to that in the thin-flap LASIK group ( $p=0.285$ ), than that in the thick-flap LASIK group ( $p=0.161$ ).

To better study the effects of laser ablation on $\mathrm{CH}$ and $\mathrm{CRF}$, we compared the amount of change in $\mathrm{CH}$ and $\mathrm{CRF}$ per micron of ablated corneal tissue in the three groups (Figures 4 and 5). The mean reduction in $\mathrm{CH}$ per micron of ablated corneal tissue was greatest in the thick-flap LASIK group ( $p=0.0052)$ than both the thin-flap LASIK and the ASA group. The thin-flap group and ASA showed no statistical difference $(p=0.285)$. The mean reduction in CRF per micron of ablated corneal tissue was again greater in the thick-flap LASIK group ( $p=0.112$ ) than both the thin-flap LASIK and the ASA group.

When comparing the two LASIK groups to each other (without the ASA group), the difference in reduction in $\mathrm{CH}$ and

Table I Pre- and postoperative data

\begin{tabular}{|c|c|c|c|c|c|c|c|}
\hline & \multirow[t]{2}{*}{ ASA } & \multirow[t]{2}{*}{ L-90 } & \multirow[t]{2}{*}{ L-I 30} & \multicolumn{4}{|l|}{$p$-value } \\
\hline & & & & $\begin{array}{l}\text { L-90 } \\
\text { vs ASA }\end{array}$ & $\begin{array}{l}\text { L-I30 } \\
\text { vs ASA }\end{array}$ & $\begin{array}{l}\text { L-90 vs } \\
\text { L-I30 }\end{array}$ & ANOVA \\
\hline Sample size & $\begin{array}{l}\mathrm{n}=19 \text { eyes } \\
(10 \text { patients })\end{array}$ & $\begin{array}{l}\mathrm{n}=16 \text { eyes } \\
\text { (II patients) }\end{array}$ & $\begin{array}{l}\mathrm{n}=16 \text { eyes } \\
(\mathrm{I} I \text { patients) }\end{array}$ & & & & \\
\hline Mean age at time of surgery & $29.3 \pm 5.8$ years & $30.3 \pm 9.4$ years & $29.3 \pm 5.8$ years & 0.732 & 0.901 & 0.720 & 0.931 \\
\hline Mean MRSE & $-3.86 \pm 2.05 \mathrm{D}$ & $-4.35 \pm 1.43 \mathrm{D}$ & $-3.68 \pm 1.35 \mathrm{D}$ & 0.408 & 0.774 & 0.184 & 0.485 \\
\hline Mean preoperative spherical error & $-3.37 \pm 1.94 \mathrm{D}$ & $-3.64 \pm 1.23 \mathrm{D}$ & $-3.34 \pm 1.27 \mathrm{D}$ & 0.408 & 0.964 & 0.507 & 0.767 \\
\hline Mean preoperative cylindrical error & $-0.97 \pm 0.72 \mathrm{D}$ & $-1.44 \pm 1.16 \mathrm{D}$ & $-0.58 \pm 0.44 \mathrm{D}$ & 0.408 & 0.054 & 0.012 & 0.017 \\
\hline Mean preoperative corneal thickness & $548 \pm 45 \mu \mathrm{m}$ & $539 \pm 37 \mu \mathrm{m}$ & $560 \pm 33 \mu \mathrm{m}$ & 0.483 & 0.411 & 0.105 & 0.329 \\
\hline Mean central ablation depth & $61 \pm 24 \mu \mathrm{m}$ & $72 \pm 20 \mu \mathrm{m}$ & $59 \pm 19 \mu \mathrm{m}$ & 0.12 & 0.870 & 0.070 & 0.163 \\
\hline Mean preoperative $\mathrm{CH}$ & 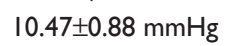 & $10.52 \pm \mathrm{I} .36 \mathrm{mmHg}$ & 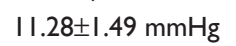 & 0.728 & 0.071 & 0.231 & 0.043 \\
\hline Mean reduction of $\mathrm{CH}$ after surgery & 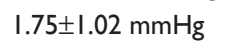 & $1.66 \pm 1.0 \mathrm{mmHg}$ & $2.62 \pm 1.03 \mathrm{mmHg}$ & 0.805 & 0.017 & 0.012 & 0.017 \\
\hline $\begin{array}{l}\text { Mean reduction of } \mathrm{CH} \text { per } \\
\text { micron of ablation depth }\end{array}$ & $0.031 \mathrm{mmHg} / \mu \mathrm{m}$ & $0.023 \mathrm{mmHg} / \mu \mathrm{m}$ & $0.049 \mathrm{mmHg} / \mu \mathrm{m}$ & 0.285 & 0.049 & 0.002 & 0.0052 \\
\hline Mean preoperative CRF & $10.1 \mathrm{I} \pm \mathrm{I} .28 \mathrm{mmHg}$ & $10.34 \pm 1.87 \mathrm{mmHg}$ & $10.62 \pm 1.76 \mathrm{mmHg}$ & 0.676 & 0.345 & 0.671 & 0.660 \\
\hline Mean reduction of CRF after surgery & $2.33 \pm 1.35 \mathrm{mmHg}$ & $2.77 \pm 1.03 \mathrm{mmHg}$ & $2.93 \pm \mathrm{I} . \mathrm{I} \mathrm{mmHg}$ & 0.285 & 0.162 & 0.681 & 0.308 \\
\hline $\begin{array}{l}\text { Mean reduction of CRF per } \\
\text { micron of ablation depth }\end{array}$ & $0.039 \mathrm{mmHg} / \mu \mathrm{m}$ & $0.040 \mathrm{mmHg} / \mu \mathrm{m}$ & $0.05 \mathrm{mmHg} / \mu \mathrm{m}$ & 0.891 & 0.076 & 0.081 & 0.112 \\
\hline
\end{tabular}

Abbreviations: ASA, advanced surface ablation; L-90, LASIK $90 \mu \mathrm{m}$ group; L- I30, LASIK I30 $\mu \mathrm{m}$ group; ANOVA, analysis of variance; MRSE, manifest refractive spherical equivalent; $\mathrm{CH}$, corneal hysteresis; $\mathrm{CRF}$, corneal resistance factor. 


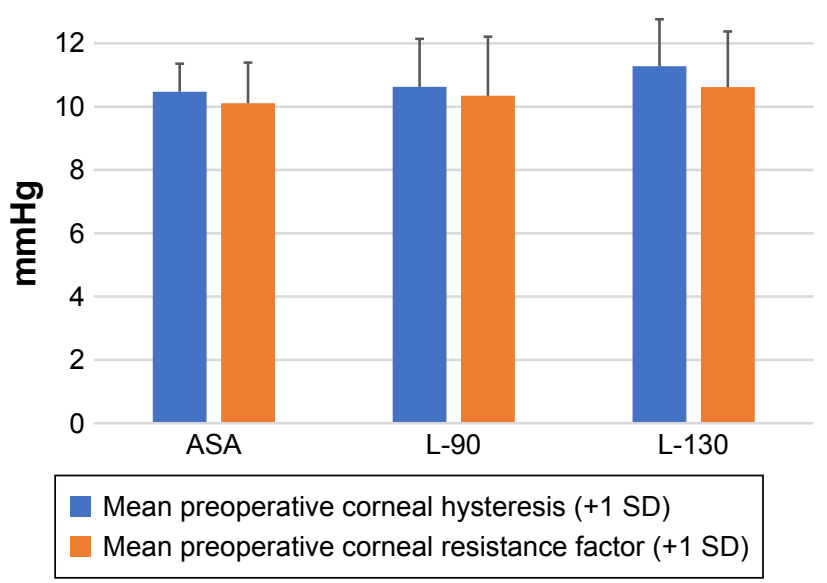

Figure I Mean preoperative corneal hysteresis and corneal resistance factor. Abbreviations: ASA, advanced surface ablation; L-90, LASIK $90 \mu \mathrm{m}$ group; L-130, LASIK $130 \mu \mathrm{m}$ group; LASIK, laser in situ keratomileusis; SD, standard deviation.

CRF became more obvious; the thick-flap group created more reduction in $\mathrm{CH}(2.62 \mathrm{mmHg})$ than the thin-flap group $(1.66 \mathrm{mmHg})$. The difference was significant for the reduction in $\mathrm{CH}(p=0.012)$, but insignificant for $\mathrm{CRF}(p=0.681)$.

When comparing the mean reduction in $\mathrm{CH}$ and CRF per micron of ablated corneal tissue between the two LASIK groups, the amount of reduction was twice greater in the thick-flap LASIK group $(0.049 \mathrm{mmHg} / \mu \mathrm{m})$ than the thinflap LASIK group $(0.023 \mathrm{mmHg} / \mu \mathrm{m})$. The difference was statistically significant for $\mathrm{CH}(p=0.002)$ and the difference for CRF $(p=0.081)$.

\section{Discussion}

In normal corneas, $\mathrm{CH}$ and $\mathrm{CRF}$ increase with increasing corneal thickness. ${ }^{11}$ Since both myopic ASA and myopic LASIK

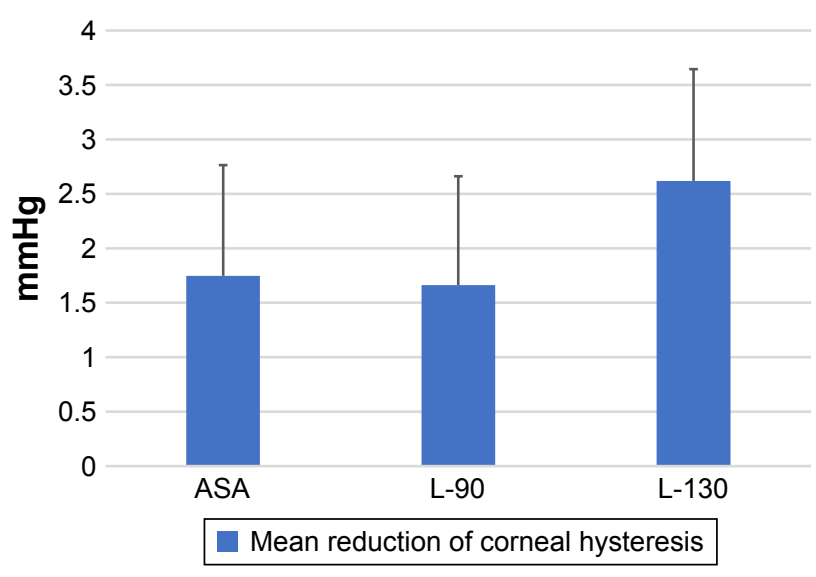

Figure 2 Mean reduction of corneal hysteresis 3 months after surgery showing a greater reduction in corneal hysteresis in the thick-flap LASIK group compared to the thin-flap LASIK and ASA groups.

Abbreviations: ASA, advanced surface ablation; L-90, LASIK $90 \mu \mathrm{m}$ group; L-130, LASIK I $30 \mu \mathrm{m}$ group; LASIK, laser in situ keratomileusis.

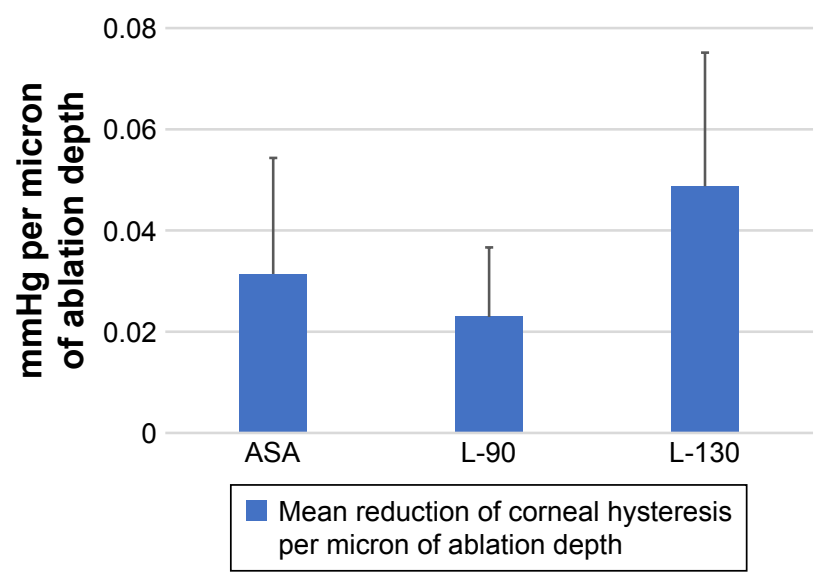

Figure 3 Mean reduction of corneal resistance factor 3 months after surgery showing a greater reduction in corneal resistance factor in the thick-flap LASIK group compared to the thin-flap LASIK and ASA groups.

Abbreviations: ASA, advanced surface ablation; L-90, LASIK $90 \mu \mathrm{m}$ group; L-130, LASIK I $30 \mu \mathrm{m}$ group; LASIK, laser in situ keratomileusis.

involve variable degrees of central corneal thinning, there is an inevitable reduction of $\mathrm{CH}$ and $\mathrm{CRF}$ with both procedures. In this study, all groups (ASA, thin-flap LASIK, thick-flap LASIK) showed reduction of $\mathrm{CH}$ and $\mathrm{CRF}$ after surgery.

Ex vivo tensile strength studies of post-LASIK corneas have revealed that the interface scar has $2.4 \%$ of the tensile strength of the normal cornea, and the LASIK flap wound margin heals with a scar $28 \%$ as strong as a normal cornea. Therefore, the remaining biomechanical strength of the LASIK-treated cornea would appear to be partially provided by the remaining residual stromal bed. ${ }^{12}$

$\mathrm{CH}$ and CRF have been shown to be lower in patients with keratoconus than in normal controls, suggesting that there is some correlation between $\mathrm{CH}$ and $\mathrm{CRF}$ and the bio-

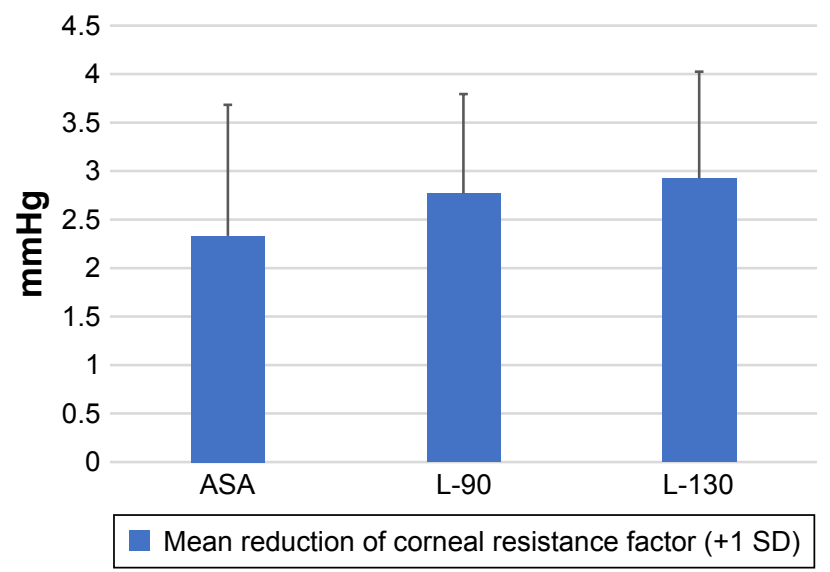

Figure 4 Mean reduction of corneal hysteresis per micron of ablation depth 3 months after surgery showing a greater reduction in corneal hysteresis in the thick-flap LASIK group compared to the thin-flap LASIK and ASA groups.

Abbreviations: ASA, advanced surface ablation; L-90, LASIK $90 \mu \mathrm{m}$ group; L- 130 , LASIK I $30 \mu \mathrm{m}$ group; LASIK, laser in situ keratomileusis; SD, standard deviation. 


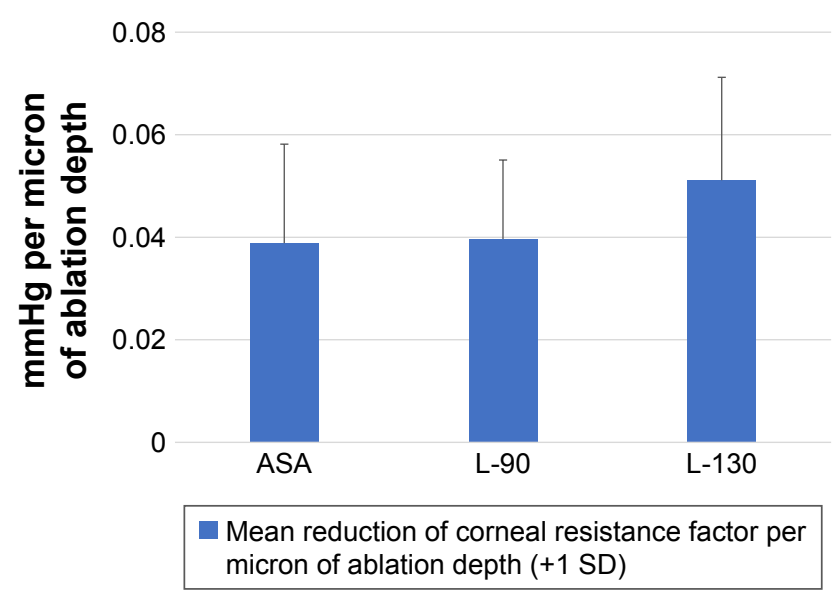

Figure $\mathbf{5}$ Mean reduction of corneal resistance factor per micron of ablation depth 3 months after surgery showing a greater reduction in corneal resistance factor in the thick-flap LASIK group compared to the thin-flap LASIK and ASA groups. Abbreviations: ASA, advanced surface ablation; L-90, LASIK $90 \mu \mathrm{m}$ group; L-130, LASIK I $30 \mu \mathrm{m}$ group; LASIK, laser in situ keratomileusis; SD, standard deviation.

mechanical strength of the cornea. ${ }^{13}$ It was also shown that LASIK decreases $\mathrm{CH}$ and CRF, but not to the extent seen in keratoconus. ${ }^{14}$ Compared to LASIK, surface ablation was found to cause even less reduction of $\mathrm{CH}$ and $\mathrm{CRF}$, providing evidence that surface ablation may better preserve corneal biomechanical integrity, presumably by avoiding the mechanical disruptive effect of a LASIK flap. ${ }^{8}$ It should be noted that the decrease in $\mathrm{CH}$ and $\mathrm{CRF}$ values stablize after 3 months and do not return to preoperative values after refractive surgery. ${ }^{15}$ Consistent with this theory, in a large case-control study of ectasia after corneal refractive surgery, $96 \%$ of cases occurred after LASIK, compared to $4 \%$ after surface ablation. ${ }^{16}$

In an experimental study involving porcine eyes, a femtosecond laser was used to create a flap of 100 or $300 \mu \mathrm{m}$, and it was found that the thicker flap was associated with a greater reduction of $\mathrm{CH}$ and $\mathrm{CRF} .{ }^{17}$ However, it is unknown whether the thickness of the flap would have a similar effect on $\mathrm{CH}$ and $\mathrm{CRF}$ in human eyes.

One study compared changes in $\mathrm{CH}$ after LASIK, using a microkeratome to create a flap thickness of $110 \mu \mathrm{m}$, and epi-LASIK. It found a greater reduction of CH in the LASIK group than the epi-LASIK group, and a strong correlation between ablation depth and change in $\mathrm{CH}$ in the LASIK group, but not in the epi-LASIK group. ${ }^{7}$ A similar study comparing biomechanical changes after PRK and LASIK, using a microkeratome $130 \mu \mathrm{m}$ head, showed a significant decrease in $\mathrm{CH}$ and CRF that is larger after LASIK than PRK. ${ }^{8}$ Another study compared the effect of LASIK, with a thick flap created using a 160 or $180 \mu \mathrm{m}$ microkeratome, versus laser-assisted subepithelial keratectomy (LASEK) on corneal biomechanics. It showed a decrease in $\mathrm{CH}$ in both the LASIK and LASEK groups, though the difference in the preoperative CCT and CRF in the LASEK group was statistically significant. ${ }^{9}$

In our study, there was a greater reduction of $\mathrm{CH}$ and $\mathrm{CRF}$ after LASIK compared to ASA. Using the ASA group as a control group, there was a greater reduction of $\mathrm{CH}$ after thickflap LASIK (130 $\mu \mathrm{m}$ head) than after thin-flap LASIK $(90 \mu \mathrm{m}$ head), that was statistically significant in the thick-flap group. The mean reduction of $\mathrm{CH}$ after thin-flap LASIK was very close to that occurring after ASA (1.66 and $1.75 \mathrm{mmHg}$, respectively), compared to $2.62 \mathrm{mmHg}$ after thick-flap LASIK.

On examining our CRF data, there was a greater reduction of CRF in both LASIK groups compared to the ASA group, although it did not attain statistical significance. However, the mean reduction in CRF was slightly higher in the thick-flap group compared to the thin-flap group (2.93 vs $2.77 \mathrm{mmHg}$, respectively). Since the mean ablation depth in the thin-flap group was greater than the thick-flap group (72 vs $59 \mu \mathrm{m}$, respectively), we calculated the mean change in CRF per micron of ablation depth, and this was found to be higher in the thick-flap LASIK group (0.051 vs $0.040 \mathrm{mmHg} / \mu \mathrm{m})$ than in the thin-flap LASIK group $(p=0.0805)$. While the difference missed statistical significance, it is worth noting that we used the two-tailed $p$-value throughout the study, as we were testing the null hypothesis in both directions. Should we have used the one-tailed $p$-value hypothesizing from the start that the reduction in the thin-flap LASIK group is greater than the thick-flap LASIK group, the difference would have been statistically significant $(p=0.045)$. Thus, after adjusting for differences in ablation depth, the mean reduction in CRF was also greater in the thick-flap group compared to the thin-flap group. It is also notable that the mean change in CRF per micron of ablation depth was very similar in the ASA and thin-flap groups (respectively, 0.039 and $0.040 \mathrm{mmHg} / \mu \mathrm{m})(p=0.891)$.

Combining these data, it appears that LASIK with a $90 \mu \mathrm{m}$ microkeratome head is very similar to ASA in terms of its effect on corneal biomechanics, whereas the use of a $130 \mu \mathrm{m}$ flap causes a greater reduction of $\mathrm{CH}$ and $\mathrm{CRF}$.

\section{Limitations}

There were some limitations in this study. We acknowledge that our sample size is small. However, there was an evident trend for greater reduction of $\mathrm{CH}$ after thick-flap LASIK compared to ASA and thin-flap LASIK, and a larger number of patients would have probably yielded greater statistical significance. In addition, selection bias led to a trend for greater ablation depth in the thin-LASIK group, and greater 
preoperative corneal thickness and $\mathrm{CH}$ in the thick-LASIK group. We attempted to compensate for these differences by computing the degree of change in $\mathrm{CH} / \mathrm{CRF}$ per unit of ablation depth. This admittedly assumes a linear relationship between $\mathrm{CH} / \mathrm{CRF}$ and ablation depth, which may not be the case. Regarding duration of follow-up, a longer period would have definitely been more confirmatory of our findings. Our decision to suffice with 3 months of follow-up was based on previous work that demonstrated that changes in $\mathrm{CH} / \mathrm{CRF}$ after keratorefractive surgery stabilize at 3 months. ${ }^{10}$

Another limitation was the absence of a mean to verify the flap thickness after surgery. Optical coherence tomography or ultrasound biomicroscopy would have been useful in this respect. Previous studies have shown that the M-2 microkeratome tends to overcut, on average, by $10-15 \mu \mathrm{m}$, such that a $90 \mu \mathrm{m}$ head produces a mean flap thickness of $110-115 \mu \mathrm{m}$, and a $130 \mu \mathrm{m}$ head produces a mean flap thickness of $140-145 \mu \mathrm{m} .{ }^{18-20}$

Studies of cohesive tensile strength of the cornea have revealed that this is strongest in the anterior $40 \%$ of the corneal stroma, decreasing progressively in deeper layers of the stroma. ${ }^{21}$ This strength is also greater in the periphery of the cornea compared to the center, due to the existence of a proportionately greater number of oblique collagen fibers in the corneal periphery. ${ }^{22}$ It follows that the circular cut into the anterior peripheral stroma during creation of a LASIK flap should produce per se some reduction of corneal biomechanical strength. Furthermore, a deeper circular cut into the anterior stroma (associated with a thicker LASIK flap) should produce an even greater effect in this respect. The results of this study confirm this hypothesis.

Although not addressed in this study, a femtosecond laser-created flap should produce less disruption of biomechanical corneal strength than a microkeratome-created flap with the same planned thickness. This is due to the planar configuration of a femtosecond flap with a relatively uniform flap thickness, in contrast to the meniscus shape of a microkeratome flap, where the peripheral lamellar cut tends to occur at a deeper level than the central portion of the cut. Previous studies have confirmed this. ${ }^{23}$

\section{Conclusion}

A thinner LASIK flap was associated with less effect on corneal biomechanics than a thicker flap, and ASA and thin-flap LASIK were found to be biomechanically similar. Therefore, in higher refractive errors where ASA is not feasible, a thinner LASIK flap could minimize corneal weakening and decrease the chance of LASIK-induced ectasia.

\section{Acknowledgment}

This study was presented at the Annual Symposium and Congress of the American Society of Cataract and Refractive Surgery, Chicago, IL, USA (April 2012).

\section{Disclosure}

The authors report no conflicts of interest in this work.

\section{References}

1. Pallikaris I, Kymionis G, Astyrakakis N. Corneal ectasia induced by laser in situ keratomileusis. J Cataract Refract Surg. 2001;27(11): 1796-1802.

2. Randleman J, Russell B, Ward M, Thompson K, Stulting R. Risk factors and prognosis for corneal ectasia after LASIK. Ophthalmology. 2003;110(2):267-275.

3. Ambrósio RJ, Dawson D, Salomão M, Guerra F, Caiado A, Belin M. Corneal ectasia after LASIK despite low preoperative risk: tomographic and biomechanical findings in the unoperated, stable, fellow eye. $J$ Refract Surg. 2010;26(11):906-911.

4. Luce DA. Determining in vivo biomechanical properties of the cornea with an ocular response analyzer. $J$ Cataract Refract Surg. 2005;31(1):156-162.

5. Dupps WJ. Hysteresis: new mechanospeak for the ophthalmologist. $J$ Cataract Refract Surg. 2007;33(9):1499-1501.

6. Shortt A, Allan B, Evans J. Laser-assisted in-situ keratomileusis (LASIK) versus photorefractive keratectomy (PRK) for myopia. Cochrane Database Syst Rev. 2013;1:CD005135.

7. Zhang L, Wang Y, Yang X. Ablation depth and its effects on corneal biomechanical changes in laser in situ keratomileusis and epipolis laser in situ keratomileusis. Int Ophthalmol. 2014;34(2):157-164.

8. Kamiya K, Shimizu K, Ohmoto F. Comparison of the changes in corneal biomechanical properties after photorefractive keratectomy and laser in situ keratomileusis. Cornea. 2009;28(7):765-769.

9. Qazi M, Sanderson J, Mahmoud A, Yoon E, Roberts C, Pepose J. Postoperative changes in intraocular pressure and corneal biomechanical metrics: laser in situ keratomileusis versus laser-assisted subepithelial keratectomy. J Cataract Refract Surg. 2009;35(10):1774-1788.

10. Kamiya K, Shimizu K, Ohmoto F. Time course of corneal biomechanical parameters after laser in situ keratomileusis. Ophthalmic Res. 2009;3:167-171.

11. Shah S, Laiquzzaman M, Cunliffe I, Mantry S. The use of the Reichert ocular response analyser to establish the relationship between ocular hysteresis, corneal resistance factor and central corneal thickness in normal eyes. Cont Lens Anterior Eye. 2006;29(5):257-262.

12. Schmack I, Dawson D, McCarey B, Waring G, Grossniklaus H, Edelhauser H. Cohesive tensile strength of human LASIK wounds with histologic, ultrastructural, and clinical correlations. J Refract Surg. 2005;21(5):433-445.

13. Shah S, Laiquzzaman M, Bhojwani R, Mantry S, Cunliffe I. Assessment of the biomechanical properties of the cornea with the ocular response analyzer in normal and keratoconic eyes. Invest Ophthalmol Vis Sci. 2007;48(7):3026-3031.

14. Ortiz D, Piñero D, Shabayek M, Arnalich-Montiel F, Alió J. Corneal biomechanical properties in normal, post-laser in situ keratomileusis, and keratoconic eyes. J Cataract Refract Surg. 2007;33(8):1371-1375.

15. Ryan D, Coe C, Howard R, Edwards J, Bower K. Corneal biomechanics following epi-LASIK. $J$ Refract Surg. 2011;27(6):458-464.

16. Randleman J, Woodward M, Lynn M, Stulting R. Risk assessment for ectasia after corneal refractive surgery. Ophthalmology. 2008; 115(1):37-50.

17. Medeiros F, Sinha-Roy A, Alves M, Dupps WJ. Biomechanical corneal changes induced by different flap thickness created by femtosecond laser. Clinics (Sao Paulo). 2011;66(6):1067-1071. 
18. Muallem M, Yoo S, Romano A, Schiffman J, Culbertson W. Corneal flap thickness in laser in situ keratomileusis using the Moria M2 microkeratome. J Cataract Refract Surg. 2004;30(9):1902-1908.

19. Talamo J, Meltzer J, Gardner J. Reproducibility of flap thickness with IntraLase FS and Moria LSK-1 and M2 microkeratomes. $J$ Refract Surg. 2006;22(6):556-561.

20. Huhtala A, Pietilä J, Mäkinen P, Suominen S, Seppänen M, Uusitalo H. Corneal flap thickness with the Moria M2 single-use head 90 microkeratome. Acta Ophthalmol Scand. 2007;85(4):401-406.
21. Randleman J, Dawson D, Grossniklaus H, McCarey B, Edelhauser H Depth-dependent cohesive tensile strength in human donor corneas: implications for refractive surgery. J Refract Surg. 2008;24(1):S85-S89.

22. Smolek M, McCarey B. Interlamellar adhesive strength in human eyebank corneas. Invest Ophthalmol Vis Sci. 1990;31(6):1087-1095.

23. Hamilton D, Johnson R, Lee N, Bourla N. Differences in the corneal biomechanical effects of surface ablation compared with laser in situ keratomileusis using a microkeratome or femtosecond laser. J Cataract Refract Surg. 2008;34(12):2049-2056.

\section{Publish your work in this journal}

Clinical Ophthalmology is an international, peer-reviewed journa covering all subspecialties within ophthalmology. Key topics include: Optometry; Visual science; Pharmacology and drug therapy in eye diseases; Basic Sciences; Primary and Secondary eye care; Patien Safety and Quality of Care Improvements. This journal is indexed on

Submit your manuscript here: http://www.dovepress.com/clinical-ophthalmology-journal

\section{Dovepress}

PubMed Central and CAS, and is the official journal of The Society of Clinical Ophthalmology (SCO). The manuscript management system is completely online and includes a very quick and fair peer-review system, which is all easy to use. Visit http://www.dovepress.com/ testimonials.php to read real quotes from published authors. 